International Journal of Education, Learning and Development

Vol.8, No.1, pp.66-76, January 2020

Published by ECRTD-UK

Print ISSN: 2054-6297(Print), Online ISSN: 2054-6300(Online)

\title{
EFFECT OF BLENDED LEARNING ON STUDENTS' RETENTION OF PHYSICS IN FEDERAL COLLEGES OF EDUCATION IN SOUTH EAST, NIGERIA
}

\section{Onyenma Chinwendu}

Department of Curriculum and Instruction, Alvan Ikoku Federal College of Education, Owerri

Olele, Clara Nnoduka

Department of Curriculum Studies and Educational Technology

University of Port Harcourt

\begin{abstract}
The study investigated the effect of blended learning on the retention of Physics by students in Federal Colleges of Education in South East, Nigeria. Two research objectives, two research questions as well as two research hypotheses guided the study. The population of the study comprised all the 287 Physics student in the three Federal Colleges of Education in South East, Nigeria. A sample of 81 students were purposively selected for the study from two of the three colleges. The instrument for data collection was a-50 multiple choice researcher-made test entitled Researcher Made Electromagnetic Theory Achievement Test (RMETAT).Test retest method was used to ensure the reliability of the instrument. Reliability coefficients of temporal stability of 0.97 and that of internal consistency of 0.72 were determined for the instrument. Mean, standard deviation and ANCOVA were the statistical tools used for data analysis. The study found out that blended learning increased the retention of Physics by students who participated in the study. It was also found out that the retention of the Physics contents by the students were not dependent upon their gender. The researcher, therefore among other things recommended that blended learning should be made a compulsory teaching strategy for Colleges of Education and similar institutions and that compulsory periodic training and retraining of teachers in institutions of higher learning on 21st century teaching strategies such as blended learning be put in place.
\end{abstract}

KEYWORDS: blended learning, retention, physics

\section{INTRODUCTION}

Retention is the process by which new information is transferred from our short term to our longterm memory. In other words, it's all about making new knowledge stick (Andriotis, 2017). Retention is the act of retaining. Merram-Webster (2018) said that to retain sometime means to keep in possession or use. Knowledge retention therefore can then be defined as the act or process of keeping in possession and using of knowledge. According to Andrew and Rebello(2013), retention of learned information can be defined as having the information stored in long-term memory in such a way that it can be readily retrieved, for example, in response to standard prompts. The study of retention clearly overlaps with the study of memory, but differs in that for information to be viewed as retained, students must be able to recall it when appropriate in response to prompts 
International Journal of Education, Learning and Development

Vol.8, No.1, pp.66-76, January 2020

Published by ECRTD-UK

Print ISSN: 2054-6297(Print), Online ISSN: 2054-6300(Online)

such as those usually found in schools and not merely in response to experiential cues, such as the smell of freshly baked bread.

Furthermore, academic retention on the other hand is a measure of the length of time a student can remember the content he or she was exposed to in a particular course. It goes a long way to tell us how much of what was learnt by a student was able to go to the long term memory. As Deslauriers and Wieman(2011:1) put it, "What is important in education is not what students know the day of the final exam, but rather what learning they retain and can apply months and years later."

Students tend to study for exam and grades they make. After the exam, they tend to forget much of what they learn. But knowledge is supposed to have a long term application even in life situations as well as workplaces after school. This being the case students should be made to pass through learning experiences that will help them retain the knowledge they gain for a long time after exams so they can apply them somewhere else after.

Physics is a subject that has many applications in the world of science and technology of today. Research findings and observation have shown that there is a low retention of contents in Physics by both male and female students, even those of them in Colleges of Education (Deslauriers and Wieman, 2011). This could be traceable to the methods and/or strategies used in teaching physics which is mainly the traditional method(face to face) strategy where an instructor writes equations on the blackboard with a lecture hall full of students taking note(Nicholas, 2012; Mekonnen, 2014). The case is not different in Colleges of education. This calls for attention as the students of these colleges are pre-service teachers who would always be the physics teachers of the secondary schools of tomorrow. Since the 21st century students are digital natives who use computers, social media and other emerging technologies daily usually for socialising. There is therefore, the need to incorporate elements of the computer, mobile phones internet and online resources into teaching and learning of physics. This approach known as blended learning is likely to make it more participatory, collaborative and interactive and has the potentials to improve the retention of Physics contents by students.

Blended learning can be seen in a general sense as a combination of learning methods or strategies as well as modalities, but most definitions seem to see it as a blend of the traditional (face-to-face) learning method with online learning. According to Graham (2016:6), "blended learning is a term that refers to a combination of traditional face-to-face instruction and technology-mediated instruction. Less commonly used terms in the research are "hybrid" and "mixed-mode" learning environments?" Singh and Reed as cited in Yapici \& Akbayin(2012:4) posited that: " blended learning is the transfer of "right" skills to the "right" person at the "right" time by matching the "right" learning technologies with the "right" learning style for the purpose of achieving the learning objectives." Jonathan (2014:3), said that "the basic principle is that face-to-face oral communication and online written communication are optimally integrated such that the strengths of each are blended into a unique learning experience congruent with the context and intended educational purpose." For Tandoh, Flis and Blankson(2014:2), "The most common approach to blended education involves embedding face-to-face instruction with web-based techniques and instructional tools." 
International Journal of Education, Learning and Development

Vol.8, No.1, pp.66-76, January 2020

Published by ECRTD-UK

Print ISSN: 2054-6297(Print), Online ISSN: 2054-6300(Online)

Again, blended learning is defined as a pedagogical approach that explicitly integrates online and face-to-face learning, and where students have meaningful interactions with their teacher with and without the mediation of electronic technology (Waha \& Davis, 2014). In blended learning, various event-based activities are mixed together(Jonathan, 2014). These activities include: selfpaced learning, live e-learning and face-to-face classrooms. Self-paced learning is what the learner does by executing the e-learning process and can be taken at the learner's leisure irrespective of time and place thereby helping him to learn at his own pace and providing the right skills at the right time. Live e-learning takes place in a virtual classroom at a scheduled time which learners undertake to attend. This enables them to collaborate with one another, share ideas, and ask questions in real time.

\section{Purpose of the study}

1. Determine the difference in the performance of Physics students taught with flipped classroom strategy and that of those taught with discussion strategy at retention test;

2. Find out the difference in the performance of male and female Physics students taught with flipped classroom strategy at retention test;

\section{Research Questions}

1. What is the difference between the mean performance scores of Physics students taught with flipped classroom strategy and that of those taught with discussion strategy at retention test?

2. What is the difference between the mean performance scores of male and female Physics students taught with flipped classroom strategy at retention test?

\section{Hypotheses}

1. There is no significant difference between the mean performance scores of Physics students taught with flipped classroom and that of those taught with the discussion strategy at retention test; 2. There is no significant difference between the mean performance scores of male and female Physics students taught with flipped classroom strategy at retention test;

\section{METHODOLOGY}

The study adopted the non-equivalent control group quasi experimental design otherwise known as the pre-test, post-test, control group design and involved one level of experimental (flipped classroom model of blended learning,) and one control group (traditional teaching method), with the student-teacher discussion strategy was used. The unit course, Phy 451, electromagnetic theory was the course taught. Retention was the dependent variable while gender served as the moderating variable. The population of the study consisted of all the Physics students in the three Colleges of Education in the study. They were 287 in number (168 males and 119 females). 
International Journal of Education, Learning and Development

Vol.8, No.1, pp.66-76, January 2020

Published by ECRTD-UK

Print ISSN: 2054-6297(Print), Online ISSN: 2054-6300(Online)

Table 1: Population Distribution of 1st Degree Physics Students in Federal Colleges of Education in South East, Nigeria.

\begin{tabular}{|lcccc|}
\hline School & A & B & C & Total \\
\hline No of Males & 78 & 68 & 22 & 119 \\
& & & & \\
& & & & \\
$\begin{array}{l}\text { No of Females } \\
\text { Total }\end{array}$ & 68 & 37 & 14 & 168 \\
& 146 & 105 & 36 & 287 \\
\hline
\end{tabular}

(Source, Physics Dept. of the Schools)

The researcher purposively selected two of the three schools. Final year Physics students of the two institutions were purposively sampled in intact class. They were 81 in number. Table 2: Sample Distribution of Final year Physics Students in Federal Colleges of Education in South East, Nigeria.

\begin{tabular}{|lccc|}
\hline School & A & B & Total \\
\hline No of Males & 29 & 12 & 41 \\
No of females & 31 & 09 & 40 \\
Total & 60 & 21 & 81 \\
\hline
\end{tabular}

(Source, Physics Dept. of the Schools)

The instrument for data collection was a fifty multiple choice question entitled "Researcher-Made Electromagnetic Theory Achievement Test"(RMETAT). Researcher made electromagnetic theory achievement test (RMETAT) questions consisted of a test of the cognitive learning outcomes in physics(Electromagnetic theory) based on the course content of the unit course( Phy 451 Electromagnetic theory) as studied at the final year level in Colleges of Education and were fifty in number. The fifty multiple choice Researcher Made Electromagnetic Theory Achievement Test was developed from the course content, lesson notes and past question papers from the Physics Department of the various institutions as well as materials from the internet.

The instrument was given to two experts from the Department of Physics and one from Measurement and Evaluation. The researcher added and removed certain items to the instrument based on the inputs made by the experts. A pilot test was carried out for the instrument,(Researcher Made Electromagnetic Theory Achievement Test(RMETAT) and the test retest method was used to determine the reliability of the instrument. Pearson Product Moment Correlation was used to determine the reliability coefficient of temporal stability of RMETAT as 0.97 and the KuderRichardson Twenty(K-20) formula used to determine the reliability coefficient of internal consistency of 0.72 for the instrument.

The study lasted for Sven (7) weeks. The first week was used to familiarise with the subjects as well as the research assistants, the actual study lasted for six(6) weeks. A pretest was given at the 
Vol.8, No.1, pp.66-76, January 2020

Published by ECRTD-UK

Print ISSN: 2054-6297(Print), Online ISSN: 2054-6300(Online)

beginning of each topic and a posttest at the end of it. Another test, the retention test was administered one month after the posttest to collect data on the extent at which the students were able to retain the concepts taught as a result of the treatment

The experimental procedure was organised into the following namely: the pre-treatment, treatment and post-treatment phases:

\section{Pre-treatment phase:}

The researcher visited the schools and the departments where the study was carried out and familiarised himself with the participants as well as train research assistant to assist him during the experiment. These were lecturers in the department who were familiar with the students and have been teaching them. Their role included to help him administer both the pre-test and post test, as well as to make sure that the procedures for the study were not hindered in any way.

\section{Treatment Phase:}

The researcher gave the treatment i.e. exposing the experimental group to lessons using the blended learning(flipped classroom) strategy through the help of the trained assistants. The treatment consisted of six lessons taught the students using the flipped classroom model of the blended learning. The lessons were on six topics in electromagnetic theory which consisted of the following in the sequence in which they were taught for the six weeks:

i. Maxwell's equation in differential form

ii. Maxwell's equation in integral form

iii. Poyting vector

iv. Waveguides

v. Transmission lines

vi. Antenna arrays

These were taught using the lesson plans prepared for this purpose. Each lesson lasted for one week. For each of the lessons, the students were sent youtube video links that contain videos on the lesson to be presented to a class group whatsapp page created for the purpose of the research. Those that did not have smartphones were given CDs containing the videos to watch at home. This served as the flipped classroom. During the face-to- face classroom, they also had the opportunity of watching the videos again but now in groups each of which had a leader who had to present a summary of their discussions on the videos to the entire class afterwards. The teacher as a facilitator supervised the activities and gave a summary at the end of each class.

Post-treatment stage:

Data were collected from the tests(pretest and posttest) as well as the retention test administered during and after the course of the treatment respectively. Mean and standard deviation were used to answer the research questions while the analysis of covariance (ANCOVA) was used to test the hypotheses at an alpha level of 0.05 . 
International Journal of Education, Learning and Development

Vol.8, No.1, pp.66-76, January 2020

Published by ECRTD-UK

Print ISSN: 2054-6297(Print), Online ISSN: 2054-6300(Online)

\section{RESULTS}

Research Question 1: What is the difference between the mean performance scores of Physics students taught with flipped classroom strategy and that of those taught with discussion strategy at retention test?

Table 3: Analysis of mean scores of the performance of Physics students taught with flipped classroom strategy and that of those taught with the discussion strategy at retention test.

\begin{tabular}{lccccc}
\hline Strategy & Pretest & \multicolumn{2}{c}{ Retention test } & Mean \\
& $\overline{\mathrm{x}}$ & SD & $\overline{\mathrm{x}}$ & SD & \\
\hline & & & & & \\
Flipped classroom & 12.37 & 4.50 & 24.86 & 4.83 & 6.61 \\
Discussion learning & 13.62 & 4.50 & 18.25 & 6.45 &
\end{tabular}

Table 3 shows that the mean scores of Physics students taught with flipped classroom strategy and that of those taught with the discussion strategy at retention are 24.86 and 18.25 respectively. Table 3 also shows that the difference in the means is 6.61. It can therefore be inferred that there is a difference in the performance mean scores of physics students taught with flipped classroom strategy and that of those taught with the discussion strategy at retention test, and the experimental group (flipped classroom) has a higher mean than the control group. This difference in the mean is an indication that the blended learning (flipped classroom) helped in the retention of Physics contents taught more than the face to -face (discussion) strategy.

Research Question 2: What is the difference between the mean performance scores of male and female Physics students taught with flipped classroom strategy at retention test?

Table 4: Analysis of mean scores on the performance of male and female Physics students taught with flipped classroom strategy at retention test

\begin{tabular}{lccccc}
\hline Gender & \multicolumn{2}{c}{ Pretest } & \multicolumn{2}{c}{ Retention test } & Mean Difference \\
& $\overline{\mathrm{x}}$ & SD & $\overline{\mathrm{x}}$ & SD & \\
\hline & & & & & \\
Male & 12.17 & 4.50 & 25.80 & 4.58 & 1.73 \\
Female & 12.57 & 4.50 & 24.07 & 4.00 & \\
& & & & & \\
\hline
\end{tabular}


Table 4 shows that the mean scores of male and female Physics students taught with flipped classroom strategy at retention test is 25.80 are and 24.07 respectively. The table also shows that there is a slight of 1.73 exists. It can be therefore inferred that there is a mean score difference between male and female students taught with flipped classroom strategy at retention, and male group has a slightly higher mean than the female, an indication that the male students had a slight higher retention of the concepts taught.

Hypothesis 1 : There is no significant difference between the mean performance scores of Physics students taught with flipped classroom strategy and that of those taught with the discussion strategy at retention test

Table 5 Result of ANCOVA testing the null hypothesis that there is no significant difference between the mean performance scores of physics students taught with flipped classroom strategy and that of those taught with the discussion strategy at posttest.

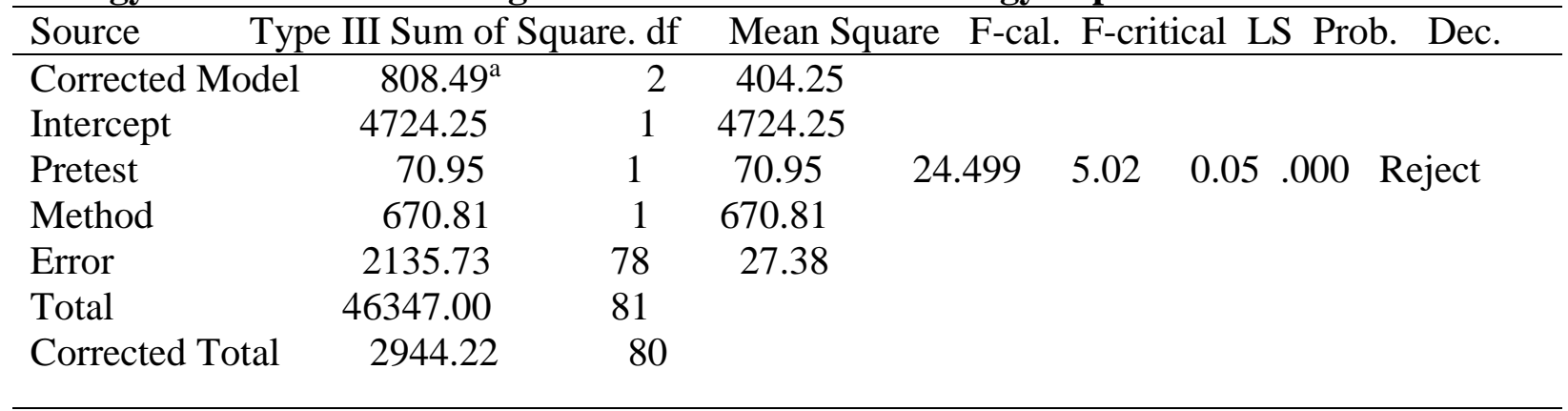

Table 5 shows that the F-computed (24.50) is greater than F-critical (5.02), and the level of significance (0.05) is greater than the probability (0.00). The result rejects the null hypothesis that there is no significant mean score difference in the performance of Physics students taught with blended learning(flipped classroom) strategy and that of those taught with the discussion strategy at retention and accepts the alternative. This difference in the mean is an indication that the blended learning(flipped classroom) helped in the retention of Physics more than the face to face(discussion) strategy.

Hypothesis 2: There is no significant difference between the mean performance scores of male and female Physics students taught with flipped classroom at retention test; 
International Journal of Education, Learning and Development

Vol.8, No.1, pp.66-76, January 2020

Published by ECRTD-UK

Print ISSN: 2054-6297(Print), Online ISSN: 2054-6300(Online)

Table 6: Result of ANCOVA testing the null hypothesis that there is no significant difference between the performance mean scores of male and female physics students taught with flipped classroom strategy at retention test.

Type III Sum of Mean

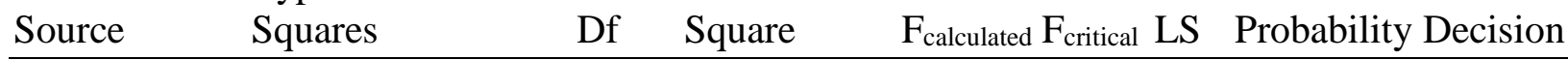

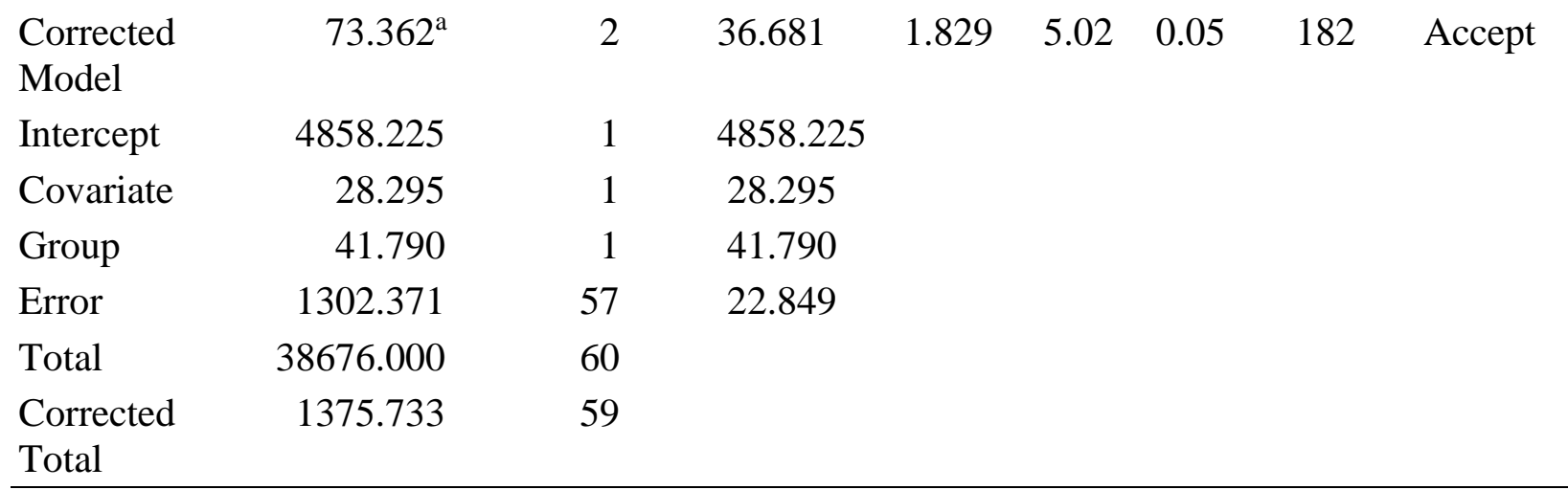

Table 6 shows that the F-computed (1.83) is less than F-critical (5.02), and the level of significance $(0.05)$ is less than the probability (0.18). This result accepts the null hypothesis that there is no significant effect of gender on the performance mean scores of physics students taught with flipped strategy at retention test. This means that the extent at which a student retains the concepts taught did not depend on whether he was a male or female.

\section{SUMMARY OF FINDINGS}

The study found out that the retention mean of the experimental group (flipped classroom model of blended learning) is higher than that of the traditional (face-to-face classroom discussion) and that the mean difference is significant.

Gender did not have any significant effect on the retention of Physics by students.

\section{DISCUSSION OF FINDINGS}

Performance of Physics students taught with blended learning and those taughtwith discussion strategy at retention test?

The result shows that the mean scores of Physics students taught with blended learning strategy and that of those taught with the discussion strategy at post are 24.86 and 18.25 respectively. This means that the difference in the mean scores is 6.61 and statistical analysis also shows that a significant difference exist between the means of the two strategies (Table 5). This means that the treatment group exposed to the blended learning strategy (flipped classroom) did show a better performance at retention, that is to say that the group had a better retention of the concepts it was 
International Journal of Education, Learning and Development

Vol.8, No.1, pp.66-76, January 2020

Published by ECRTD-UK

Print ISSN: 2054-6297(Print), Online ISSN: 2054-6300(Online)

exposed to than the control group which was exposed to the traditional (discussion) strategy. Thus, blended learning increased the retention of Physics by the students who participated in the study. This result agrees with the findings of Hinampas, Rhesa, Murillo, Catherine, Tan, Denis, Layosa \& Roxette. (2018), in a study carried out to investigate the effectiveness of blended learning based on the learning management system "Blackboard" in immediate and delayed achievement and retention in a physics course among Health Colleges students at KSU in which the result showed that the blended learning based on "Blackboard" had a positive longitudinal effect on retention among Health Colleges students at KSU, while the traditional method was not effective. It is also in line with the result of the study of Suleiman, Salaudeen and Falode(2017) which investigated the effects of Computer-based blended learning strategy on Secondary School Chemistry students' retention in individualised and collaborative learning settings in Minna, Niger State, Nigeria. The study found out that the Computer-Based Blended learning strategy improved students' retention in chemistry in collaborative learning settings better than in individualized learning setting and in lecture method.

\section{Effect of gender on the academic performance of physics students taught with flipped classroom strategy at retention test.}

The result shows that the mean scores of male and female Physics students taught with flipped classroom strategy at retention test is 25.80 are and 24.07 respectively, that is, a mean score difference of 1.73 exists. The result of the statistical analysis also shows that the difference is not statistically significant. It goes a long way to prove that though the male students who were exposed to the flipped classroom strategy tend to have performed slightly better (had a better retention of the concepts) than their female counterpart, yet the difference is not really of any significant effect. Gender therefore is not an indicator of whether students retain Physics concepts longer or not.

\section{CONCLUSION}

The following conclusions were made by the researcher:

1. The study found out that the retention mean of the experimental group (flipped classroom model of blended learning) was higher than that of the traditional (face-to-face classroom discussion) and that the mean difference was significant. That is to say that the experimental group performed better at retention test meaning that blended learning (flipped classroom) tends to be a better strategy than the face-face strategy.

2. Gender did not significantly influence the retention of Physics concepts by students. Therefore, that a student retains Physics concepts for a long time is not a factor of whether the person is a male or female student.

\section{Recommendations}

The researcher recommends that:

1. Blended learning should be made a compulsory teaching strategy for Colleges of Education and similar institutions.

2. Compulsory professional training in the knowledge and use of ICT should be made a part of the teacher training programmes of schools such as Universities and Colleges of Education. 
International Journal of Education, Learning and Development

Vol.8, No.1, pp.66-76, January 2020

Published by ECRTD-UK

Print ISSN: 2054-6297(Print), Online ISSN: 2054-6300(Online)

3. There should be a periodic training and retraining of teachers on 21 st century teaching strategies such as computer and ICT based teaching strategies one of which is blended learning

4. Investments in digital teaching and learning materials is needed in our institutions of higher learning

\section{References}

Andrew, J.B \& Rebello, N.S.(2013), Retention and Learning, in Norbert, M.S.(ed), Encyclopediof the sciences of learning. Retrieved from https://link.springer.com/referenceworkentry/ 10.1007\%2F978-1-4419-1428-6_664

Andriotis, N. (2018). Make your eLearning stick: 8 tips \& techniques for learning retention. Retrieved from https://www.talentlms.com/blog/8-tips-techniques-learning-retention/)

Deslauriers, L. \& Wieman, C. (2011). Learning and retention of quantum concepts with different teaching methods, - Physics education research 7(010101), 1-6. Retrieved from http://www.cwsei.ubc.ca/SEI_research/files/Physics/Deslauriers- Wieman_ Quantum QuantumRetention_PRST-PER_2011.pdf

Graham, C.R. (2016). Blended Learning. Retrieved from http://curtbonk.com/graham_intro.pdf

Hinampas, P, Rhesa, R Murillo, J, Catherine, Tan, Denis, Layosa \& Roxette. (2018). Blended Learning Approach: Effect On Students' Academic Achievement And Practical Skills In Science Laboratories. International Journal of Scientific \& Technology Research, 7(6369.

Jonathan, O.C.(2014). Challenges facing effective utilization of blended learning model in teacher education programmes in nigeria. A paper presented at 10th Annual National Conference of Qualitative Education in Nigeria (ASSEQEN) with the Theme Reorienting and Alternative Education to Build a Better Future for All at the Benue State University Markurdi between 12th - 16th May 2014. Retrieved from http://www.unn.edu.ng/publications/files/12302_Challenges_facing_Effective_Utilizatio n_of_Blended_Learning_Model_in_Teacher_Education_Programmes_in_Nigeria.pdf

Merram-Webster (2018) Definition of retention. Retrieved from https://www.merriamwebster.com/dictionary/retention

Mekonnen, S. (2014). Problems Challenging the Academic Performance of Physics Students in Higher Governmental Institutions in the Case of Arbaminch, Wolayita Sodo, Hawassa and Dilla Universities. Natural Science, 6: 362-375. Retrieved from http://dx.doi. org/10. 4236/ns.2014.65037.

Nicolas, M.N.(2012). Investigation into causes of poor performance in KCSE Physics among form four students in Thika. Kenyatta University Repository. Retrieved from https://irlibrary.ku.ac/handle/ 123456 789/2227?show=full

Tandoh, K., Flis, N. \& Blankson(2014). Blended Learning: History, Implementation, Benefits, and Challenges in Higher Education. Retrieved from www.igi-global.com/chapter/ /blended-learning/92962

Waha, B., \& Davis, K. (2014). University students' perspective on blended learning. Journal of Higher Education Policy and Management, 36(2), 172-182. 
International Journal of Education, Learning and Development

Vol.8, No.1, pp.66-76, January 2020

Published by ECRTD-UK

Print ISSN: 2054-6297(Print), Online ISSN: 2054-6300(Online)

Yapci, U. \& Akbayin, H.(2012). The effect of blended learning model on high school students' biology achievement and on their attitudes towards the internet. Turkish Online Journal of Educational Technology 11(2): 228-237. Retrieved from https://www.academia.edu/ 1493077/The_Effect_of_Blended_Learning_Model_on_High_School_Students_Biology _Achievement_and_on_their_Attitudes_towards_the_Internet 